\title{
THE INTERACTION OF DRUGS, WITH PARTICULAR REFERENCE TO ANAESTHETIC PRACTICE*
}

\author{
Leonard C. Jenkins, B.A., M.D., C.M., F.R.C.P. (c) $\uparrow$
}

The physician, pharmacist, and pharmaceutical manufacturer's medical representative have a responsibility to the public, in their presentation of drugs. This is readily realized when it is considered that all drugs carry with them the possibility of having deleterious effects on the patient. These effects may result from overdosage, known side-effects, unknown side-effects, allergic responses, hypersensitivity reactions, or inadvertent administration, in spite of known contraindications to the use of the drug. Remembering the contraindications and sideeffects of even the commonest drugs in use today is a formidable task. There has been a tremendous increase in the number of therapeutic agents marketed. Many of these are potent. They have equally potent side-effects and specific contraindications. Their exact mode of action is often not known, and their pharmacological effects are frequently widespread. Many drugs on the market closely resemble each other, and often the same drug is distributed under different trade names. It has become difficult to retain a safe working knowledge of drugs used even in a restricted field.

Recently, in addition, the problems and hazards associated with the interaction between drugs have received widespread attention..$^{1,2}$ The potential for interaction between drugs has increased significantly in recent years, as has been forcefully demonstrated by a recent review by Jick and Chalmers, ${ }^{3}$ who perused issues of the Journal of the American Medical Association and showed that in 1950 there were, in two issues, 22 advertisements for orally administered drugs, of which only two had two or more ingredients. By contrast, in two issues each in 1962 and 1964 there were 120 advertisements for oral medication; of which 52 , nearly half, contained combinations of two or more agents. Wilson ${ }^{4}$ in 1962 showed that, of 169 new drug products introduced in Britain in 1961, a total of 113 (67\%) were in effect combinations of drugs.

The tendency to prescribe combinations of the many new potentially useful remedies has encouraged the marketing of fixed-ratio combinations. The major increases in new drugs have been in the fields of steroids, hypnotics, tranquillizers and analgesics, psychotropic drugs, hypotensives, diuretics, and antibiotics. Temptations have been frequent to prescribe drugs from these groups in combination. For instance, a recent study at Johns Hopkins Hospital ${ }^{5}$ showed that for patients who were given penicillin an average of 14 other drugs (the range being 6-32) were prescribed during their hospital stay. Such patients, often candidates for

'Presented at the Annual Meeting of the Canadian Anaesthetists' Society, Montreal, June 1967.

†Associate Professor, Division of Anaesthesiology, Department of Surgery, and Lecturer and Research Associate, Department of Pharmacology, Faculty of Medicine, University of British Columbia. 
surgery, may then in the course of anaesthesia have multiple drugs superimposed upon this preoperative level. The polypharmaceutical approach to the conduct of anaesthesia creates a potential basis for the interaction of drugs during anaesthesia.

The clinical situations in which interaction between drugs can occur in anaesthesia are principally three:

1. From a single mixture by the anaesthesiologist.

2. From separate administration within a short interval by the same anaesthesiologist.

3. From administration by separate physicians (surgeons, attending physicians, and anaesthesiologists), each unaware of the other's drug administration.

Thus, in some instances the risk may lie in the interaction of different agents given by the anaesthetist (1) as a single mixture or (2) separately with short intervening intervals. How many of our single mixtures-for example atropine combined with prostigmine-may produce interaction effects which, although not grossly apparent, as with succinylcholine and thiopentone mixture, nevertheless may create unknown pharmacological and/or chemical alterations in their constituents? In other clinical situations the interaction may be due (3) to drugs given by the patient's attending physician or surgeon before anaesthesia. Each physician, including the anaesthetist, may be unaware of the other's treatment. Anaesthetic agents may then introduce factors that make the previously administered agent a hazardous one. The introduction of antidepressant monoamine oxidase inhibitors (MAOI) exemplifies this type of problem, which has recently been reviewed in relation to anaesthesia. ${ }^{6}$

The known sites and mechanisms of interaction between drugs are schematically summarized in Figure 1 and discussed below.

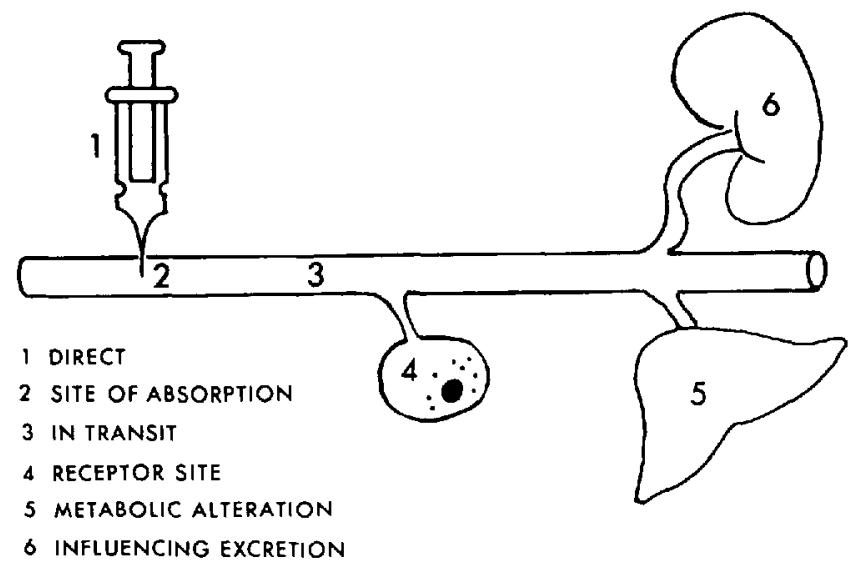

Figure 1. Sites and mechanisms of drug interaction.

1. Direct interaction. There can be a direct effect of one compound upon another, such as the intentional neutralization of heparin with protamine. ${ }^{7}$ This is an example, also, of a useful drug interaction. The basic protamine (rich in 
arginine) combines with the strongly acidic heparin to form a stable salt with loss of anticoagulant activity.

2. Absorptive site interaction. Intestinal or intramuscular absorption of drugs, for instance, may be modified by procedures that alter the $\mathrm{pH}$, or provide particular ions. ${ }^{1}$

3. In transit interaction (displacement from combination with plasma proteins). The transport of a drug within the circulation may be affected by the concomitant administration of another drug, which may displace it from a particular protein component. The medium of drug transfer is the water or plasma and extracellular fluid. Without complicating factors, the level of drug at a receptor site would be equal to that in the tissues and in plasma, and in dynamic equilibrium. Actually, almost all drugs are reversibly bound to proteins in plasma or tissue. The bound drug, often a high proportion of the total, acts as a reservoir, preventing wild fluctuations between ineffective and toxic levels of the biologically active unbound fraction. ${ }^{8}$ Displacement from a receptor site diminishes drug activity, but displacement from in transit (carrier) plasma or tissue proteins augments the effect by making more unbound drug available at the receptor site. ${ }^{8}$ There may be dramatic effects such as hypoglycaemia, when highly bound sulfonamides such as sulfaphenazole are given to patients on tolbutamide, ${ }^{\theta}$ or bleeding when phenylbutazone is given to patients on warfarin. ${ }^{10}$

A recent study indicates that, in human subjects anaesthetized with thiopentone, the neuromuscular blocking effect of succinylcholine is increased by the intravenous injection of procaine or lidocaine, administered either before or after succinylcholine. ${ }^{11}$ It was hypothesized that lidocaine and lower doses of procaine displace bound succinylcholine from circulating (carrier receptor) plasma proteins, allowing an increase in active unbound succinylcholine to act at the receptor site, and resulting in potentiation of succinylcholine-induced apnoea. This would suggest care in the dose of succinylcholine when treating local anaesthetic-induced convulsions with succinylcholine, an approach currently in vogue ${ }^{12}$ or when surgical anaesthesia is attained by some anaesthetists with a combination of intravenous local anaesthetics, succinylcholine, and nitrous oxide. ${ }^{13,14}$

4. At or near receptor site. Atropine has no intrinsic activity, but displaces pilocarpine or acetylcholine competitively from receptor sites at postganglionic muscarinic parasympathetic effector nerve endings. Similarly, reserpine competes with noradrenaline or aramine at sympathetic nerve endings, but is in turn displaced by amphetamine-like drugs. 8,15

5. Influencing excretion. Thiazides, by increasing excretion of potassium and thus diminishing the plasma concentration of potassium, potentiate the toxicity potential of digitalis. ${ }^{16}$ Sodium bicarbonate, by increasing the urinary $\mathrm{pH}$, increases the excretion of barbiturates (particularly phenobarbitone) and thus tends to diminish their toxicity, when in overdose. Ammonium chloride, by making the urinary $\mathrm{pH}$ more acid, accelerates the excretion of meperidine. ${ }^{15,17}$ For both these examples, there are risks of accumulation by decreased excretion when the urinary $\mathrm{pH}$ changes in the opposite direction. Thus the phenomenon of $\mathrm{pH}$-dependent excretion is of practical importance. In general, an acidic or 
basic drug may be expected to show the phenomenon of $\mathrm{pH}$-dependent excretion if the unionized fraction is lipoid-soluble and if the $\mathrm{pK}$ is within a favourable range of 7.5-10.5 for weak bases and 3.0-7.5 for weak acids. Weak acids are excreted at a higher clearance in highly alkaline urine, and weak bases in acidic urine. Drugs which are known to show the phenomenon of $\mathrm{pH}$-dependent excretion include the weak acids salicylic acid, phenobarbitone, nitrofurantoin, nalidixic acid, and some sulphonamides, and the weak bases mepacrine, chloroquine, nicotine, procaine, mecamylamine, pempidine, pethidine, levorphanal, quinine, amphetamine, imipramine, and amitryptiline. ${ }^{18}$

6. Accelerating or slowing drug metabolism. Studies in recent years have disclosed that interaction between drugs may alter their metabolism by enzyme stimulation and inhibition. ${ }^{19}$ These effects have been well studied in experimental animals and they now appear to have importance in man. ${ }^{20-23}$ Enzymes in liver microsomes, which metabolize many clinically useful drugs, are associated with the smooth-surfaced endoplasmic reticulum in the liver cell. They are quite versatile in metabolizing drugs by various reactions. ${ }^{19}$ Interaction of some drugs can either stimulate or inhibit the metabolism of drugs by these enzymes.

Inhibition of drug metabolism. Many examples are now known of drugs which can inhibit the metabolic detoxification of other drugs and thus cause an increase in their duration and intensity of pharmacological action. ${ }^{24,26}$ For instance, Weiner and his associates ${ }^{26}$ recently reported that the plasma levels of bishydroxycoumarin and the anticoagulant response to the drug were prolonged in human subjects treated with oxyphenbutazone. Also, it is now well documented that patients treated with monoamine oxidase inhibitors such as tranylcypramine and iproniazid are unusually sensitive to a subsequent dose of sympathomimetic amines, which are metabolized by this enzyme. ${ }^{6,19}$

Stimulation of drug metabolism. The chronic administration of one drug can reduce the pharmacological activity of another drug by stimulating its metabolic inactivation. Drugs exert this action by increasing the amount of drug-metabolizing enzymes in liver microsomes. This is referred to as enzyme induction. ${ }^{27}$ Electron microscopic studies have shown that the increase in enzyme activity is accompanied by a marked proliferation of smooth-surfaced endoplasmic reticulum of the liver cell. ${ }^{28,29}$ Drug metabolism can be stimulated by different types of drugs. Table I lists some recorded examples of enzyme induction drug interactions.

A problem that may develop from enzyme induction of dicoumarol by chloral hydrate is illustrated by the following sequence in one of our patients. The patient was receiving therapeutic doses of dicoumarol for thrombophlebitis of the lower limb veins. She also received chloral hydrate as evening sedation. While the chloral hydrate was being discontinued and replaced with secobarbital, her prothrombin time tripled and her blood level of dicoumarol more than doubled, even though there was no change in the daily dose of dicoumarol. A similar (fatal) case reported recently by Cucinell ${ }^{30}$ indicates that chloral hydrate may stimulate metabolism of dicoumarol by enzyme induction. Thus, in order to achieve therapeutic prothrombin times, the dose of dicoumarol was 
TABLE I

Drugs Involved in Enzyme Induction

\begin{tabular}{|c|c|}
\hline Potentiated drug & Agent of enzyme induction* \\
\hline Coumarin derivatives & $\begin{array}{l}\text { barbiturates }{ }^{19,31} \\
\text { chloral hydrate } \\
\text { halogenated hydrocarbons } \\
34\end{array}$ \\
\hline Diphenylhydantoin & barbiturates 31,32 \\
\hline Zoxazolamine & barbiturates ${ }^{2 \theta}$ \\
\hline Grise of ulvin & barbiturates ${ }^{33}$ \\
\hline Barbiturates & chlorcyclizine $^{35}$ \\
\hline Meprobamate & phenobarbital 22,36 \\
\hline Pentobarbital & chlorpromazine $\mathrm{e}^{36}$ \\
\hline
\end{tabular}

kept high while the patient was on chloral hydrate. But when the chloral hydrate was discontinued and replaced with a drug that did not stimulate metabolism of dicoumarol by enzyme induction, the rate of metabolism of dicoumarol decreased, the plasma level of dicoumarol eventually became elevated, and the prothrombin time increased.

\section{SUMMARY}

The effects of drug combinations have certain characteristic properties produced by the interaction of the physiological-pharmacological effects of the constituents. The results may be:

1. Inapparent. Potential interaction between drugs may be of little significance or even quite inapparent, if the side-effects are opposite in nature and equal in strength.

2. Antagonistic. Some types of antagonism may be dangerous, or they may be merely inconvenient.

3. Synergistic. Synergistic action of drugs may result from (a) summated actions, and/or (b) potentiated actions which may be desirable if unwanted side-effects of each component can be "filtered out," but undesirable if unforeseen exaggeration of the desired effect occurs.

With greater awareness and understanding of the underlying mechanisms, the many untoward interactions now being increasingly reported might be foreseen and avoided.

\section{Résumé}

Le médecin, le pharmacien et le représentant des manufacturiers de produits pharmaceutiques ont une responsabilité envers le public dans la présentation des médicaments.

Récemment, on a attiré l'attention sur les problèmes et les risques reliés à l'interaction des médicaments entr'eux. Au cours des dernières années, la 
possibilité d'interaction entre les médicaments a augmenté de façon marquée. Dans la pratique de l'anesthésie, la chose est plus patente.

Les situations cliniques, en anesthésie, où l'interaction entre les médicaments peut s'observer sont: (1) Lors d'un simple mélange. (2) Lors de l'administration par le même anesthésiste de doses séparées de différents médicaments à de courts intervalles. (3) Lors de l'administration de médicaments par différents médecins (chirurgiens, médecins traitants et anesthésistes) qui ignorent que d'autres médicaments ont été donnés.

Les endroits et les mécanismes de l'interaction des médicaments sont: (1) l'interaction directe, (2) l'interaction au site d'absorption, (3) l'interaction de transport (déplacement de l'association avec les protéines du plasma), (4) à l'endroit des récepteurs, (5) en accélérant ou en ralentissant le métabolisme des médicaments, (6) en agissant sur l'excrétion.

Les effets de l'interaction des médicaments entre eux résultent de leur combinaison qui modifie leurs propriétés caractéristiques par l'interaction des effets pharmaceutiques et physiologiques des constituents. Il peut s'ensuivre: (1) aucun symptome (si les effets sont égaux et opposés), (2) un antagonisme, (3) une synergie (pouvant inclure une sommation et une potentialisation.

Nous avons cité des exemples de médicaments associés à l'anesthésie et à la chirurgie qui ont présenté des phénomènes d'interaction et nous avons parlé de l'influence de ces interactions sur la conduite de l'anesthésie.

En étant plus averti et en comprenant mieux les mécanismes en cause, il est possible de prévoir et d'éviter les nombreuses interactions indésirables que l'on observe et que l'on rapporte de plus en plus.

\section{REFERENCES}

1. Mackregor, A. G. Symposium on Interaction between Drugs, Proc. Roy. Soc. Med. 58: 943 (1965).

2. Editorial: Interaction of Drugs. Brit.M.J. 1: 811-812 (1966).

3. Jick, H. \& Chalmens, T. C. Editorial: Drug Combinations-Uses, Dangers and Fallacies. Clin. Pharmacol. \& Therap. 5: 673 (1964).

4. WILson, G. M. The Interaction of Drugs in Medicine. In Symposium on Clinical Trials. Pharmaceutical Society of Great Britain. London (1962), p. 53.

5. ClufF, L. E. Studies on the Epidermiology of Adverse Drug Reactions: I. Methods of Surveillance. J.A.M.A., 188: 976 (1964).

6. Jenknss, L. C. \& Graves, H. B. Potential Hazards of Psychoactive Drugs in Association with Anaesthesia. Canad. Anaesth. Soc. J., 12: 121 (1965).

7. Chargaff, E. \& Olson, K. B. Studies on the Chemistry of Blood Coagulation: VI. Studies on the Action of Heparin and Other Anticoagulants: The Influence of Protamine on the Anticoagulant Effect in Vivo. J. Biol. Chem., 122: 153 (1937).

8. Brodie, B. B. Displacement of One Drug by Another from Carrier or Receptor Sites: In Symposium on Interaction between Drugs. Proc. Roy. Soc. Med. 58: 946 (1965).

9. Christensen, L. K.; Hansen, J. M.; \& Kristensen, M. Sulphaphenazole-induced Hypoglycaemia Attacks in Tolbutamide-treated Diabetes. Lancet ii: 1298 (1963).

10. Eisen, M. J. Combined Effect of Sodium Warfarin and Phenylbutazone, J.A.M.A. 189: $64(1964)$.

11. Usublaga, J. E.; Wikinski, J. A.; Morales, R. L.; \& Usubiaga, L. E. J. Interaction of Intravenously Administered Procaine, Lidocaine and Succinylcholine in Anesthetized Subjects. Anesth, \& Analg. 46: 39 (1967).

12. De Konnfeld, T. J. \& Strinhaus, J. E. The Effect of Intravenously Administered Lidocaine and Succinylcholine on the Respiratory Activity of Dogs. Anesth. \& Analg. 38: $173(1959)$. 
13. Parada, J. F. \& Malina, F. J. Intravenous Procaine Anesthesia: An Argentine Technique. Proc. First European Cong. Anesth. 2: 152 (1962).

14. Usubiaga, J. E. \& Wikinski, J. A. Uso da procaina intravenosa em anestesia general. Rev. brasil. Anest. 14: 400 (1964).

15. Goodman, L. S. \& Gilman, A. The Pharmacological Basis of Therapeutics. New York; Macmillan (1965), 523, 569, 500, 846.

16. Lown, B. \& Levine, H. D. Atrial Arrhythmias, Digitalis and Potassium. New York: Landsberger Medical Books (1958).

17. Asatoon, A. M.; Galman, B. R.; Johnson, J. R.; \& Mnne, M. D. The Excretion of Dexamphetamine and Its Derivatives. Brit. J. Pharmacol. 24: 293 (1965).

18. Milne, M. D. Influence of Acid-Base Balance on Efficiency and Toxicity of Drugs. In Symposium on Interaction between Drugs. Proc. Roy. Soc. Med. 58: 961 (1965).

19. Burns, J. J. \& Conney, A. H. Enzyme Stimulation and Inhibition with Metabolism of Drugs. In Symposium on Interaction between Drugs. Proc. Roy. Soc. Med. 58: 955 (1965).

20. Conney, A. H. \& Burns, J. J. Factors Influencing Drug Metabolism. Adv. Pharmacol. 1: 31 (1962).

21. Remmen, H. Enzyme Induction and Inhibition. In Ciba Foundation Symposium on Enzymes and Drug Action. Ed. J. L. Mongar and A. V. S. De Reuck. Boston (1962), p. 276.

22. BunNs, J. J. Editorial: Implications of Enzyme Induction for Drug Therapy. Am. J. Med. $37: 327$ (1964).

23. Fouts, J. R. Editorial: Drug Interactions: Effects of Drugs and Chemicals on Drug Metabolism. Gastroenterology. 46: 486 (1964).

24. Burns, J. J.; Rose, R. K.; Goodwin, S.; Reichenthal, J.; Horning, E. C.; \& Brodie, B. B. The Metabolic Fate of Phenylbutazone (Butazolidin) in Man. J. Pharmacol. Exper. Therap. 113: 481 (1955).

25. Bunns, J. J.; Conney, A. H.; Colville, K. I.; \& Sansur, M. Interaction between Drugs. Pharmacologist. 5: 250 (1963).

26. Weiner, M.; Smdiqui, A. A.; Bostanci, N.; \& Dayton, P. G. Drug Interactions: The Effect of Combined Administration on the Half-life of Coumarin and Pyrazolone Drugs in Man. Fed. Proc. 24: 153 (1965).

27. Conney, A. H. \& Burns, J. J. Enzyme Induction. In Symposium on Regulation of Enzyme Activity and Synthesis in Normal and Neoplastic Liver. Ed. G. Weliu. New York (1963), p. 189.

28. Fouts, J. R. \& Rogers, L. A. Morphological Changes in the Liver Accompanying Stimulation of Microsomal Drug Metabolizing Enzyme Activity by Phenobarbital, Chlordane, Benzpyrene or Methylcholanthrene in Rats. J. Pharmacol. Exper. Therap. 147: 112 (1965).

29. Conney, A. H.; Davison, C.; Gostel, R.; \& Burns, J. J. Adaptive Increases in Drugmetabolizing Enzymes Induced by Phenobarbital and Other Drugs, J. Pharmacol. Exper. Therap. 130: 1 (1960).

30. Cucinell, S. A.; Odesskx, L.; Weiss, M.; \& Dayton, P. G. The Effect of Chloral Hydrate on Bishydroxycoumarin Metabolism: A Fatal Outcome. J.A.M.A. 197: 366 (1966).

31. Cucinell, S. A.; Conney, A. H.; Sansur, M.; \& Burns, J. J. Drug Interactions in Man. I. Lowering Effect of Phenobarbital on Plasma Levels of Bishydroxycoumarin (Dicumarol) and Diphenylhydrantoin (Dilantin). Clin. Pharmacol. Therap. 6: 420 (1965).

32. Cucinell, S. A.; Koster, R.; Conney, A. H. \& Burns, J. J. Stimulatory Effect of Phenobarbital on the Metabolism of Diphenylhydantoin. J. Pharmacol. \& Exper. Therap. 141: 157 (1963).

33. Busfield, D.; Child, K. J.; \& Tomich, E. G. An Effect of Phenobarbitone on Griseofulvin Metabolism in the Rat. Brit. J. Pharmacol. 22: 137 (1964).

34. Burns, J. J.; Cucinell, S. A.; Koster, R.; \& Conney, A. H. Application of Drug Metabolism to Drug Toxicity Studies. Ann. N.Y. Acad. Sc. 123: 273 (1965).

35. WerK, E. E. Jr.; MacGee, J.; \& Sholiton, L. J. Effect of Diphenylhydantoin on Cortisal Metabolism in Man. J. Clin. Invest. 43: 1824 (1964).

36. Shepherd, M. Psychotropic Drugs: I. Interaction between Centrally Acting Drugs in Man: Some General Considerations. In Symposium on Interaction between Drugs. Proc. Roy. Soc. Med. 58: 964 (1965). 